\title{
PENGARUH MEDIA AUDIO TERHADAP KETERAMPILAN MENYIMAK DAN BERBICARA BAHASA ARAB
}

\author{
Mahmudah \\ Prodi Pendidikan Guru Madrasah Ibtidaiyah Fakultas Tarbiyah dan Keguruan \\ Universitas Islam Negeri Antasari Banjarmasin \\ Email: mahmudah@uin-antasari.ac.id
}

\begin{abstract}
This study aims to find the effect of the use of audio media on listening skills and speaking Arabic in class IV MIN 13 Banjar students. This research method is experimental research with preexperimental designs with one-group pretest-posttest design model. From the analysis of normal test data and linearity, the data are normally and linearly distributed. From the data correlation test and regression test to get the 0.002 correlation significance means that there is a correlation, and a simple regression test value of 0.673 . So explain of this study is that audio media has a positive effect on speaking skills and there is a significant correlation between listening and speaking skills.
\end{abstract}

Keywords: Media; Audio; Skills; Listening; Speaking

\begin{abstract}
ABSTRAK
Penelitian ini bertujuan untuk mengetahui pengaruh penggunaan media audio terhadap keterampilan menyimak serta berbicara Bahasa Arab siswa kelas IV MIN 13 Banjar. Metode penelitian ini adalah penelitian eksperimen dengan desain pre-experimental designs dengan model one-group pretestposttest design. Dari analisis data uji normal dan linieritas data berdistribusi normal dan linear. Dari uji korelasi data dan uji regresi mendapatkan hasil signifikansi korelasi $\mathbf{0 , 0 0 2}$ berarti terdapat korelasi,dan nilai uji regresi sederhana $\mathbf{0 , 6 7 3}$. Sehingga kesimpulan dari penelitian ini adalah media audio berpengaruh positif terhadap keterampilan berbicara dan terdapat korelasi yang signifikan antara keterampilan menyimak dan berbicara.
\end{abstract}

Kata Kunci : Media; Audio; Keterampilan; Menyimak; Berbicara

\section{Pendahuluan}

Seiring berkembangnya zaman serta ilmu pengetahuan dan teknologi yang semakin pesat seperti yang terjadi sekarang ini, menyebabkan semakin berkembang juga dalam dunia pendidikan. Pada hakekatnya pendidikan adalah proses membantu membangun manusia dalam mengembangkan diri agar dapat menghadapi segala macam tantangan dan rintangan yang dihadapi pada suatu bangsa agar mencapai tujuan yang dikehendaki. Pendidikan merupakan hal terpenting dalam kehidupan manusia yang tentunya menjadi salah satu tempat untuk melatih seseorang dalam terampil berbahasa.
Undang-Undang Nomor 20 Tahun 2003 tentang Sistem Pendidikan Nasional, Pasal 1 angka 1 menyatakan bahwa pendidikan adalah usaha sadar dan terencana untuk mewujudkan suasana belajar dan proses pembelajaran agar siswa secara aktif mengembangkan potensi dirinya untuk memiliki kekuatan spiritual keagamaan, pengendalian diri, kepribadian, kecerdasan, akhlak mulia, serta keterampilan yang diperlukan dirinya, masyarakat, bangsa dan negara (Permendikbud No. 65 Tahun 2013 tentang Standar Proses Pendidikan Dasar dan Menengah). 
Wine Sanjaya mengkritisi konsep pendidikan menurut UndangUndang Nomor 20 Tahun 2003 tersebut : (Sanjaya,2006:2)

1. Pendidikan adalah usaha sadar yang terencana, hal ini berarti proses pendidikan di sekolah bukanlah proses yang dilaksanakan secara asal-asalan dan untung-untungan, akan tetapi proses yang bertujuan sehingga segala sesuatu yang dilakukan guru dan siswa diarahkan pada pencapaian tujuan.

2. Proses pendidikan yang terencana itu adalah diarahkan untuk mewujudkan suasana belajar dan juga proses pembelajaran, berarti pendidikan tidak boleh mengesampingkan proses belajar. Pendidikan tidak semata-mata berusaha untuk mencapai hasil belajar, tetapi bagaimana mem-peroleh hasil atau proses belajar yang terjadi pada diri anak.

3. Suasana belajar dan pembelajaran itu diarahkan agar peserta didik dapat mengembangkan potensi dirinya, ini berarti proses pendidikan itu harus berorientasi kepada siswa.

4. Akhir dari proses pendidikan adalah kemampuan anak memiliki kekuatan spiritual keagamaan, pengendalian diri, kepribadian, kecerdasan, akhlak mulia, serta keterampilan yang diperlukan dirinya, masyarakat, bangsa, dan negara. Hal ini berarti proses pendidikan berujung kepada pembentukan sikap, pengembangan kecerdasan atau intelektual, serta pengembangan keterampilan anak sesuai dengan kebutuhan.

Di dalam pendidikan formal yang telah dilakukan di sekolah, ada banyak mata pelajaran yang membuat peserta didik terampil dan mampu dalam berbagai hal, salah satunya adalah berbahasa yang baik dan benar. Di sekolah, ada 3 bahasa yang umum nya diajarkan, yaitu Bahasa Indonesia, Bahasa Inggris, dan Bahasa Arab. Pada penelitian ini, peneliti memfokuskan pada pembelajaran Bahasa Arab, karena Bahasa Arab merupakan salah satu pelajaran yang dianggap sulit oleh siswa, ini membuat peneliti tertarik untuk menjadikan pelajaran ini sebagai fokus utama.

Dalam mempelajari Bahasa Arab, seorang siswa diharapkan dapat menguasai keterampilan bahasa yang baik dan benar, terdapat empat aspek yang perlu untuk diperhatikan dalam memahami keterampilanketerampilan berbahasa, khususnya keterampilan berbahasa Arab, keempat aspek tersebut adalah : keterampilan menyimak, keterampilan berbicara, keterampilan membaca, dan keterampilan menulis. Keempat keterampilan tersebut erat kaitannya dan saling menunjang atau mendukung satu sama lain. Keberhasilan seseorang dalam menyimak dapat diketahui dari bagaimana penyimak mampu memahami lalu menyampaikan informasi dari hasil simakan secara lisan atau tertulis. Menyimak adalah dasar yang cukup penting untuk menunjang keterampilan berbicara, karena apa yang akan kita ucap dalam berbicara merupakan hasil simakan dari pembicaraan orang lain.

Dengan begitu keterampilan menyimak dapat dikatakan sebagai salah satu pondasi dalam belajar berbahasa. Kita analogikan saja balita yang baru mampu berbicara, mereka akan menggunakan bahasa ibu atau bahasa yang mereka dengar sehari hari, ini membuktikan bahwa proses berbicara tersebut merupakan lanjutan dari menyimak.

Keterampilan menyimak dan berbicara merupakan keterampilan bahasa yang lebih dulu ada bila dibandingkan dengan keterampilan membaca dam menulis. Ini dapat dibuktikan dengan sejarah jauh sebelum manusia mengenal tulisan dan dapat menulis, keterampilan menyimak dan berbicara sudah digunakan manusia sebagai alat komunikasi antar sesamanya. Kemudian ketika manusia mengenal tulisan barulah keterampilan membaca dan menulis berkembang, mulailah surat menyurat digunakan sebagai sarana berkomunikasi.

Pelaksanaan pembelajaran pada lembaga pendidikan juga sebagian besar 
dilakukan melalui kegiatan menyimak. Selain kemampuan menyimak, kemampuan berbicara juga dapat menjadi sorotan yang tentu tak kalah penting, karena secara praktis kemampuan tersebut yang paling terlihat di kegiatan sehari-hari. Seperti yang sama sama kita ketahui, dalam berinteraksi dan berkomunikasi, kita cendrung menggunakan bentuk komunikasi verbal setiap harinya. Hal tersebut tentu saja membuat kemampuan berbicara menjadi penting bagi kita, yang perlu kita pelajari dan asah terus menerus.

Namun pada fakta yang ada, siswa cenderung kesulitan dalam menyimak dan berbicara dalam Bahasa Arab. Siswa menganggap palajaran bahasa arab sulit untuk di mengerti dan di praktik kan dalam berkomunikasi karena mereka takut jika salah penyebutan. Berdasarkan observasi yang dilakukan pada Madrasah Ibtidaiyah Negeri 13 Banjar, siswa belajar bahasa arab kebanyakan dengan membaca lalu menulisnya. Mengingat sekolah ini adalah sekolah yang ada di desa dan minim fasilitas, pembelajaran bahasa arab bergantung pada guru Bahasa Arab saja, tanpa ada media lain yang menunjang pembelajaran selain buku siswa yang dipinjam kan kepada siswa.

Dengan waktu pembelajaran Bahasa Arab yang juga singkat, hanya $2 \times 35$ menit dalam satu minggu, tentu pembelajaran yang efektif dan mampu meningkatkan keterampilan berbahasa anak menjadi tujuan yang di usahakan pencapaiannya. Sedangkan sistem pengajaran yang ada pada sekolah adalah penggunaan sumber pembelajaran masih terbatas pada informasi yang disampaikan oleh guru dan ditambah sedikit dari buku saja, tidak menggunakan media penunjang lain. Sehingga pembelajaran yang selama ini dilakukan guru dalam mengajar dirasa kurang efektif, karena hanya mendengarkan apa yang diucapkan guru, kemudian mencatat dan menghafal sehingga aktivitas belajar peserta didik sangat kurang berkembang.
Suatu keberhasilan dalam belajar mengajar dapat dilihat dari metode dan penggunaan media yang tepat dari seorang guru dalam sebuah pembelajaran yang dilakukan. Penggunaan media yang tepat dalam pengajaran akan mampu membangkitkan minat siswa dalam mengikuti proses pelajaran. Media pembelajaran dirasa penting bagi peningkatan kualitas pendidikan karena semakin tampak dengan perkembangan teknologi sekarang ini. Pelaksanaan pendidikan dapat diperbaharui atau ditingkatkan dengan berkembangnya teknologi. Kelengkapan media pembelajaran tentu sangat dibutuhkan untuk menunjang proses kelancaran belajar mengajar, sehingga diharapkan akan tercipta suatu pembelajaran yang menarik dan mengasyikkan bagi peserta didik.

Media pembelajaran adalah bentuk penyalur yang digunakan untuk menyalurkan sebuah pesan, informasi, maupun bahan pelajaran kepada penerima pesan. Media audio misalnya, adalah salah satu media pembelajaran yang mampu memotivasi peserta didik dalam proses belajar, sehingga siswa menjadi lebih aktif dalam merespon materi yang telah didengarnya melalui media audio. Media audio peneliti rasa menarik, karena kebanyakan siswa sudah terlalu bosan dengan ceramah yang diberikan guru, meskipun ceramah merupakan salah satu strategi yang mampu meningkatkan keterampilan menyimak pada siswa juga, namun strategi ceramah saja tanpa menggunakan media apapun, dirasa sudah tidak sesuai dengan perkembangan jaman serta membosankan bagi siswa. Ini sesuai dengan survey lapangan yang peneliti lakukan, banyak sekolah yang menggunakan metode ceramah saja tanpa menggunakan media apapun, akan membuat siswa nya bosan dan mengantuk, ini dikarenakan siswa sudah terlalu bosan dengan metode ceramah yang selalu saja digunakan guru.

Seperti yang telah dijelaskan sebelumnya, ada 3 bahasa yang umumnya di 
ajarkan pada jenjang sekolah, yaitu Bahasa Indonesia, Bahasa Inggris, dan Bahasa Arab. Namun, pada madrasah ibtidaiyah dilapangan, Bahasa Arab dan Bahasa Indonesia lah yang menjadi bahasa wajib yang diajarkan. Melalui pembelajaran Bahasa Arab, siswa diharapkan memiliki keterampilan berbahasa yang meliputi keterampilan menyimak, berbicara, membaca dan menulis. Namun yang menjadi perhatian utama dalam penelitian ini adalah harapan untuk meningkatkan kemampuan berbahasa menyimak dan berbicara karena jika, seseorang semakin banyak menyimak maka semakin baik pula kemampuannya dalam berbicara, karena saat menyimak seseorang akan menyerap kata-kata baru yang mungkin belum pernah ia dengar, dengan cara demikian maka pengetahuan kosa kataseseorang akan bertambah sehingga ia mampu untuk berbicara, yang nantinya akan di ikuti oleh mampunya ia dalam membaca dan menulis.'

Sebagai sekolah yang akan menjadi tempat penelitian, peneliti memilih MIN 13 Banjar atas 2 pertimbangan utama sebagai berikut :

1. Peneliti pernah melakukan praktik mengajar di sekolah tersebut, sehingga memudahkan peneliti dalam melakukan penelitian.

2. Peneliti mengamati bahwa pembelajaran yang berlangsung disekolah ini hanya bertopang pada guru, tanpa ada media penunjang lain yang mampu membantu kegiatan belajar mengajar.

\section{Metode Penelitian}

Metode yang digunakan dalam penelitian ini adalah penelitian eksperimen. Penelitian eksperimen adalah metode penelitian yang digunakan untuk mencari pengaruh perlakuan tertentu terhadap yang lain dalam kondisi yang terkendalikan. Adapun desain yang dipilih adalah preexperimental designs (nondesign). Desain ini belum merupakan eksperimen sungguhsungguh karena masih terdapat variabel luar yang ikut berpengaruh terhadap terbentuknya variabel dependen. Bentuk pre-experimental designs (nondesigns) yang dipilih yaitu model one-group pretest-posttest design, dalam model ini terdapat satu kelompok eksperimen kemudian diberi pretest untuk mengetahui keadaan awal kelompok eksperimen, selanjutnya diberikan perlakuan dan diberikan posttest (Sugiyono,2010:107).

Ditetapkan satu kelompok ekperimen yakni IV Madrasah Ibtidaiyah Negeri 13 Banjarmasin. Untuk mengetahui ada tidaknya pengaruh dari media audio, hal tersebut bisa dilihat dari pretest dan posttest.

Dalam penelitian ini, peneliti menggunakan dua variabel yaitu variabel yang menjadi penyebab (X) dan variabel yang menjadi akibat (Y). Variabel bebas dalam penelitian ini adalah penggunaan media audio dalam pembelajaran Bahasa Arab, dan variabel terikatnya ialah kemampuan menyimak (Y1) dan kemampuan berbicara (Y2) pada siswa.

Dalam penelitian ini, kelas IV yang menjadi populasi dan sampel diberikan tes awal untuk mengetahui kemampuan menyimak dan berbicara sebelum menggunakan media audio, hanya dengan strategi ceramah dan berpegang pada buku teks saja, tes awal ini disebut dengan pretest. Selanjutnya kelas tersebut diajarkan kembali dengan menggunakan media audio, untuk melihat besar pengaruh antara sebelum dan sesudah penggunaan media audio, maka dilakukan kembali tes menyimak dan berbicara setelah digunakannya media audio, tes ini disebut posttest.

Soal tes yang diberikan, adalah soal yang sudah terdapat pada buku siswa, sehingga dalam penelitian ini, peneliti tidak melakukan uji validitas dan reliabilitas pada intrumen soal yang diujikan pada pretest maupun posttest.

Dalam penelitian kuantitatif, analisis data merupakan kegiatan setelah seluruh data dari seluruh responden atau sumber data lain terkumpul. Dalam penelitian ini, peneliti 
menganalisis data dengan beberapa teknik, yaitu :

1. Analisis Data

Untuk menganalisis peningkatan keterampilan siswa, maka peneliti menggunakan digunakan skor gain. $N$ gain diperoleh dari pengurangan skor posttest dengan skor pretest dibagi oleh skor maksimum dikurang skor pretest.

2. Pengujian Hipotesis

Pengujian hipotesis dilakukan menggunakan tiga metode analisis dalam SPSS 17.0 yaitu:

a. Uji normalitas dilakukan terhadap hasil tes akhir (posttest)

b. Uji linearitas dilakukan untuk mengetahui dua variabel yang diuji

\section{Hasil dan Pembahasan}

Penelitian ini menggunakan one group pretesst-posttest untuk menggambarkan keadaan setelah diberikan perlakuan yang dalam penelitian ini ialah media audio. Penelitian dilakukan pada hari Sabtu, 18 Agustus 2018 pada kelas IV Madrasah Ibtidaiyah Negeri 13 Banjar. Peneliti hanya melakukan 1 kali pertemuan untuk mengukur pretesst-posttest, karena materi yang di ujikan adalah materi yang telah diajarkan pada hari sebelumnya oleh guru mata pelajaran bahasa Arab. Materi yang di ujikan adalah التَّْْرِيْفِ yang merupakan materi pertama pada kelas IV.

Berdasarkan hasil pretest yang dilakukan sebelum penggunaan media audio dengan memperhatikan keterampilan menyimak siswa dilihat dari kemampuannya menjawab pertanyaan yang telah diberikan untuk mengetahui kemampuan siswa dalam menyimak maka didapatkan hasil nilai total 1035 dari 16 orang siswa dengan rata rata nilai 64,6875 , yang diantara nya ada 3 orang siswa yang berhasil memenuhi nilai ketuntasan minimum 75 yang berarti siswa yang berhasil tuntas hanya $18,75 \%$ dalam pembelajaran. Nilai ini tentu masih sangat mempunyai hubungan yang linear atau tidak secara signifikan.

c. Uji korelasi berfungsi untuk mencari derajat keeratan hubungan dan arah hubungan, semakin tinggi nilai korelasi maka semakin tinggi keeratan hubungan kedua variabel.

Uji regresi linear sederhana digunakan untuk memprediksi nilai dari variabel terikat jika nilai variabel bebas (X) mengalami kenaikan atau penurunan dan untuk mengetahui arah hubungan antara variabel bebas $(\mathrm{X})$ dengan variabel terikat $(\mathrm{Y})$ apakah positif atau negatif. Pengujian tersebut dilakukan terpisah antara uji keterampilan menyimak dan berbicara.

jauh dari yang diharapkan dalam keterampilan menyimak.

Setelah dilakukan pembelajaran menggunakan media audio, maka didapatkan peningkatan niai siswa, dengan total nilai 1455 dan rata rata nilai 90,9375 yang berarti semua siswa berhasil mendapatkan dan melalui standar ketuntasan minimum.

Dengan telah dilakukan nya pretest dan posttest, selanjutnya peneliti melakukan analisis pertama dengan menghitung $N$-gain yang diperoleh dari pengurangan skor posttest dengan pretest dibagi dengan skor maksimum lalu dikurang skor pretest, maka didapat hasil $420: 565=0,743$, ini berarti peningkatan keterampilan menyimak setelah digunakan media audio masuk dalam kategori tinggi.

Selanjutya peneliti melakukan analisis dari data skor keteramilan berbicara untuk menguji hipotesis:

Ho : Tidak terdapat pengaruh dari penggunaan media audio terhadap keterampilan menyimak siswa pada mata pelajaran bahasa Arab.

Ha : Terdapat pengaruh dari penggunaan media audio terhadap keterampilan menyimak siswa pada mata pelajaran bahasa Arab. 
Untuk menguji hipotesis ini maka peneliti melakukan pengijiam dengan 4 metode analisis dengan hasil sebagai berikut :

a. Uji Normalitas, dilakukan terhadap hasil posttest dari keterampilan menyimak dengan uji KolmogorovSmirnov dengan menggunakan program SPSS yang berdasarkan nilai signifikansi untuk mengetahui apakah data berdistribusi secara normal/tidak. Dari hasil analisis didapatkan bahwa nilai signifikansi sebesar 0,200 lebih besar dari 0,05 , sehingga dapat disimpulkan bahwa data yang kita uji berdistribusi normal.

Tabel 1

One-Sample Kolmogorov-Smirnov Test

\begin{tabular}{|ll|r|}
\hline & & \multicolumn{1}{|c|}{$\begin{array}{c}\text { Unstandardized } \\
\text { Residual }\end{array}$} \\
\hline $\mathrm{N}$ & & 16 \\
Normal Parameters & a,b & Mean \\
& Std. & .0000000 \\
& Deviation & 5.43394155 \\
Most Extreme & Absolute & .154 \\
Differences & Positive & .115 \\
& Negative & -.154 \\
Test Statistic & & .154 \\
Asymp. Sig. (2-tailed) & & $.200^{\text {c,d }}$ \\
\hline
\end{tabular}

b. Uji Linearitas, dilakukan untuk mengetahui hubungan yang linear atau tidak signifikan, uji ini juga sebagai prasyarat dalam analisis korelasi atau regresi linear, dikatakan memiliki hubungan yang linear jika signifikansi lebih dari 0.05. dari hasil analisis didapatkan nilai signifikansi $=\mathbf{0 , 0 7 1}$ lebih dari $\mathbf{0 , 0 5}$, yang artinya terdapat hubungan linear secara signifikan dan nilai linearity 0,001 atau kurang dari 0,05 yang berarti terdapat hubungan yang linear.
Tabel 2

ANOVA Table

\begin{tabular}{|c|c|c|c|c|}
\hline & $\mathrm{df}$ & $\bar{F}$ & Sig. \\
\hline \multirow{2}{*}{\multicolumn{2}{|c|}{$\begin{array}{l}\text { Between } \\
\text { Groups } \\
\\
\quad \text { Linearity }\end{array}$}} & 4 & $\begin{array}{r}7.84 \\
9\end{array}$ & .003 \\
\hline & & 1 & $\begin{array}{r}22.0 \\
62\end{array}$ & .001 \\
\hline & $\begin{array}{l}\text { Deviation } \\
\text { from Linearity }\end{array}$ & 3 & $\begin{array}{r}3.11 \\
2\end{array}$ & .071 \\
\hline Within Gr & oups & 11 & & \\
\hline Total & & 15 & & \\
\hline
\end{tabular}

c. Uji Korelasi, peneliti lakukan untuk mencari derajat keeratan hubungan dan arah hubungan antara penggunaan media audio dengan keterampilan menyimak. Berdasarkan Nilai Signifikansi dapat diketahui nilai signifikansi $\mathbf{0 , 0 0 2}<\mathbf{0 , 0 5}$ yang berarti terdapat korelasi yang signifikan. Sedangkan berdasarkan nilai Pearson Correlation yang dihubungkan antara masing-masing variabel mempunyai tanda bintang, ini berarti terdapat korelasi yang signifiakan antara variabel yang telah di hubungkan.

Tabel 3 Correlations

\begin{tabular}{|ll|r|r|}
\hline & \multicolumn{1}{|c|}{$\begin{array}{c}\text { Pretest_Me } \\
\text { nyimak }\end{array}$} & $\begin{array}{c}\text { Posttest_Men } \\
\text { yimak }\end{array}$ \\
\hline $\begin{array}{l}\text { Prete } \\
\text { st }\end{array}$ & $\begin{array}{l}\text { Pearson } \\
\text { Correlation }\end{array}$ & 1 & $.721^{* * *}$ \\
& $\begin{array}{l}\text { Sig. (2- } \\
\text { tailed) } \\
\mathrm{N}\end{array}$ & & $\mathbf{. 0 0 2}$ \\
\hline $\begin{array}{l}\text { Postt } \\
\text { est }\end{array}$ & $\begin{array}{l}\text { Pearson } \\
\text { Correlation }\end{array}$ & $.721^{* *}$ & 16 \\
& $\begin{array}{l}\text { Sig. (2- } \\
\text { tailed) } \\
\mathrm{N}\end{array}$ & $\mathbf{. 0 0 2}$ & \\
& & 16 & 16 \\
\hline
\end{tabular}

d. Uji Regresi Linear Sederhana, sebagai pengujian terakhir dalam pengujian hipotesis ini untuk mengetahui arah hubungan antara penggunaan media audio dengan keterampilan menyimak. Pengujian regresi ini juga peneliti lakukan dengan bantuan 
SPSS, dari Unstandardized Coefficients nilainya sebesar -7,577. Angka ini merupakan angka konstan yang mempunyai arti bahwa jika tidak ada media audio maka nilai konsisten Posttest $(\mathrm{Y})$ adalah sebesar 7,577 .

Tabel 4 Coefficients $^{\mathrm{a}}$

\begin{tabular}{|c|c|c|c|c|c|}
\hline \multirow[b]{2}{*}{ Model } & \multicolumn{2}{|c|}{$\begin{array}{l}\text { Unstandardize } \\
\text { d Coefficients }\end{array}$} & $\begin{array}{l}\text { Standa } \\
\text { rdized } \\
\text { Coeffi } \\
\text { cients }\end{array}$ & \multirow[b]{2}{*}{$\mathrm{t}$} & \multirow[b]{2}{*}{ Sig. } \\
\hline & B & $\begin{array}{l}\text { Std. } \\
\text { Error }\end{array}$ & Beta & & \\
\hline 1 (Constant & 7.577 & $\begin{array}{r}18.59 \\
6\end{array}$ & & .407 & .690 \\
\hline $\begin{array}{l}\text { Posttest_- } \\
\text { Menyima } \\
\text { k }\end{array}$ & .795 & .204 & .721 & $\begin{array}{r}3.89 \\
7\end{array}$ & .002 \\
\hline
\end{tabular}

Koefesien regresi bernilai sebesar 0,795 . Angka ini mengandung arti bahwa setiap penambahan media audio maka keterampilan menyimak akan meningkat 0,795 , karena nilai koefisien regresi bernilai positif $(+)$ maka dengan demikian dapat dikatakan bahwa media audio berpengaruh positif terhadap keterampilan menymak.

Selanjutnya adalah uji hipotesis atau uji pengaruh, berfungsi untuk mengetahui apakah koefisien regresi tersebut signifikan atau tidak.

Hipotesis dalam penelitian ini adalah :

Ho : Tidak terdapat pengaruh dari penggunaan media audio terhadap keterampilan menyimak siswa pada mata pelajaran bahasa Arab.

$\mathrm{Ha}$ : Terdapat pengaruh dari penggunaan media audio terhadap keterampilan menyimak siswa pada mata pelajaran bahasa Arab.

Untuk memastikan apakah koefisien regresi tersebut signifikan atau tidak, dapat menggunaan uji hipotesis dengan cara membandingkan nilai signifikan (sig) dengan probabilitas 0.05 atau demgan membandingkan nilai $t$ hitung dengan $t$ tabel. Diketahui nilai signifikansi (Sig.) sebesar signifikansi $0,002<0,05$ probabilitas, sehingga dapat disimpulkan bahwa $\mathrm{H} 0$ ditolak dan $\mathrm{Ha}$ diterima, yang berarti bahwa "Terdapat pengaruh dari penggunaan media audio terhadap keterampilan menyimak siswa pada mata pelajaran bahasa Arab."

Tabel 5

Coefficients $^{\mathrm{a}}$

\begin{tabular}{|c|c|c|c|c|c|}
\hline \multirow[b]{2}{*}{ Model } & \multicolumn{2}{|c|}{$\begin{array}{l}\text { Unstandardize } \\
\text { d Coefficients }\end{array}$} & \multirow{2}{*}{$\begin{array}{c}\text { Standar } \\
\text { dized } \\
\text { Coeffic } \\
\text { ients }\end{array}$} & \multirow[b]{2}{*}{$\mathrm{t}$} & \multirow[b]{2}{*}{ Sig. } \\
\hline & B & $\begin{array}{l}\text { Std. } \\
\text { Error }\end{array}$ & & & \\
\hline 1 (Constant) & -7.577 & 18.596 & & .407 & .690 \\
\hline $\begin{array}{l}\text { Menyima } \\
\mathrm{k}\end{array}$ & .795 & .204 & .721 & $\begin{array}{r}3.89 \\
7\end{array}$ & .002 \\
\hline
\end{tabular}

kembali dilihat nilai t hitung sebesar 3,897 yang akan dibandingkan dengan $\mathrm{t}$ tabel. Nilai $\mathrm{t}$ table adalah $0,05 / 2=0,025$, dengan derajat kebebasan $(\mathrm{df})=\mathrm{n}-2=16-2=14$, Nilai 0,$025 ; 14$ , maka di dapat nilai t table sebesar 2,14. Karena nilai t hitung sebesar 3,897 lebih besar dari t tabel 2,14, sehingga dapat disimpulkan bahwa Ho ditolak dan Ha diterima, yang berarti bahwa "Terdapat pengaruh dari penggunaan media audio terhadap keterampilan menyimak siswa pada mata pelajaran bahasa Arab."

Berdasarkan beberapa metode analisis yang telah dilakukan, maka dapat diketahui bahwa pengaruh penggunaan media audio terhadap keterampilan menyimak ditandai dengan meningkatnya nilai peserta didik saat dilakukan postest yang masuk kedalam kategori tinggi. Kemudian dalam tahap pengujian hipotesis pun didapatkan hasil bahwa data yang diuji berdistribusi normal dengan nilai signifikansi sebesar 0,200 lebih besar dari 0,05. Pada uji linearitas juga didapat hasil signifikansi $=\mathbf{0 , 0 7 1}$ lebih dari $\mathbf{0 , 0 5}$, yang artinya terdapat hubungan linear secara signifikan dan nilai linearity 0,001 atau kurang dari 0,05 yang berarti terdapat hubungan yang linear. Selanjutnya pada uji korelasi juga didapatkan hasil signifikansi 0,002 yang kurang dari angka pembanding 
0,05 yang berarti terdapat korelasi yang signifikan dan pada nilai Pearson Correlation yang dihubungkan mempunyai tanda bintang, ini berarti terdapat korelasi yang signifiakan, dilanjutkan dengan uji regresi sederhana didapatkan koefesien regresi bernilai sebesar 0,795, karena nilai koefisien regresi bernilai positif (+) maka dengan demikian dapat dikatakan bahwa media audio berpengaruh positif terhadap keterampilan menymak, lalu untuk melihat pengaruhnya dapat dilihat dari signifikansi $\mathbf{0 , 0 0 2}$ yang kurang dari 0,05 sehingga dapat dikatakan bahwa "Terdapat pengaruh dari penggunaan media audio terhadap keterampilan menyimak siswa pada mata pelajaran bahasa Arab."

Dari Unstandardized Coefficients dalam kasus ini nilainnya sebesar 41,633. Angka ini merupakan angka konstan yang mempunyai arti bahwa jika tidak ada media audio (X) maka nilai konsisten Posttest (Y) adalah sebesar 41,633. Angka koefesien regresi nilainya sebesar 0,673. Angka ini mengandung arti bahwa setiap penambahan media audio maka keterampilan berbicara akan meningkat 0,673 , karena nilai koefisien regresi bernilai positif (+) maka dengan demikian dapat dikatakan bahwa media audio berpengaruh positif terhadap keterampilan berbicara (Y).

Selanjutnya adalah uji hipotesis atau uji pengaruh, berfungsi untuk mengetahui apakah koefisien regresi tersebut signifikan atau tidak.

Hipotesis dalam penelitian ini adalah :

Ho : Tidak terdapat pengaruh dari penggunaan media audio terhadap keterampilan berbicara siswa pada mata pelajaran bahasa Arab.

$\mathrm{Ha}$ : Terdapat pengaruh dari penggunaan media audio terhadap keterampilan berbicara siswa pada mata pelajaran bahasa Arab.

Untuk memastikan apakah koefisien regresi tersebut signifikan atau tidak, dapat menggunaan uji hipotesis dengan cara membandingkan nilai signifikan (sig) dengan probabilitas

0.05

atau

demgan membandingkan nilai t hitung dengan $\mathrm{t}$ tabel.

Diketahui nilai signifikansi (Sig.) sebesar signifikansi $0,002<0,05$ probabilitas, sehingga dapat disimpulkan bahwa $\mathrm{H} 0$ ditolak dan Ha diterima, yang berarti bahwa "Terdapat pengaruh dari penggunaan media audio terhadap keterampilan berbicara siswa pada mata pelajaran bahasa Arab."

Tabel 10

Coefficients $^{\text {a }}$

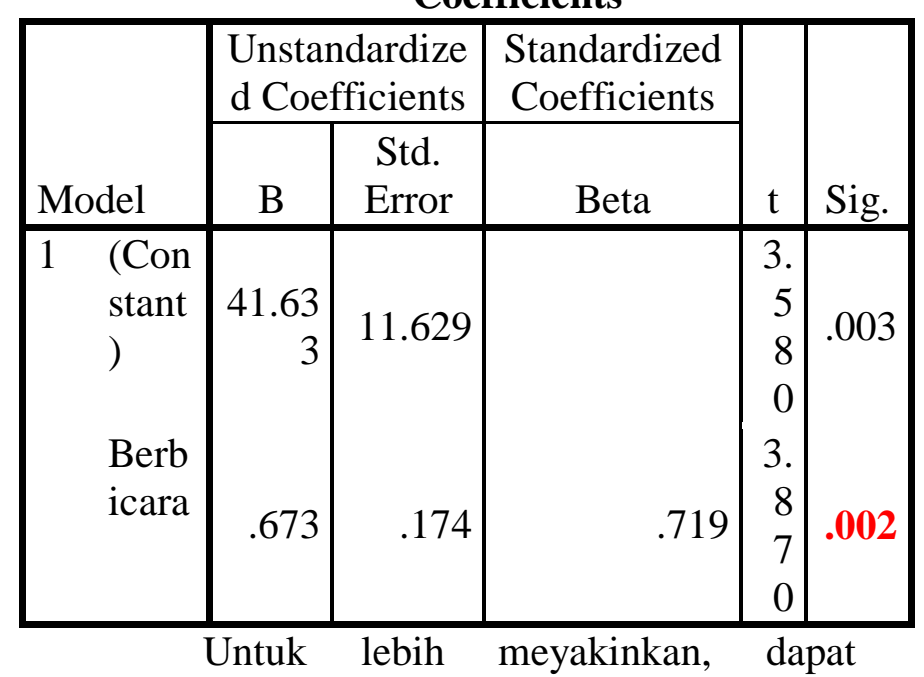

kembali dilihat nilai t hitung sebesar 3,870 yang akan dibandingkan dengan nilai t table. Nilai t tabel adalah: $0,05 / 2=0,025$, Derajat kebebasan $(\mathrm{df})=\mathrm{n}-2=16-2=14$, Nilai 0,$025 ; 14$ , maka di dapat nilai t tabel sebesar 2,14, Karena nilai t hitung sebesar 3,870 lebih besar dari > 2,14, sehingga dapat disimpulkan bahwa H0 ditolak dan $\mathrm{Ha}$ diterima, yang berarti bahwa "Terdapat pengaruh dari penggunaan media audio terhadap keterampilan berbicara siswa pada mata pelajaran bahasa Arab."

Berdasarkan beberapa metode analisis yang telah dilakukan, maka dapat diketahui bahwa pengaruh penggunaan media audio terhadap keterampilan berbicara ditandai dengan meningkatnya nilai peserta didik saat dilakukan postest yang masuk dalam kategori sedang. Kemudian dalam tahap pengujian hipotesis pun didapatkan hasil bahwa data yang diuji berdistribusi normal dengan nilai signifikansi sebesar 0,200 lebih besar dari 
0,05, sehingga dapat data yang di uji berdistribusi normal, kemudian pada uji linearitas nilai signifikansi 0,301 lebih dari 0,05 , yang artinya terdapat hubungan linear secara signifikan dan nilai linearity 0,002 atau kurang dari 0,05 yang berarti terdapat hubungan yang linear. Pada uji korelasi didapat nilai signifikansi $\mathbf{0 , 0 0 2}$ yang kurang dari angka pembanding $\mathbf{0 , 0 5}$ yang berarti terdapat korelasi yang signifikan antara media audio dengan keterampilan berbicara. Selanjutnya setelah dilakukan uji regresi sederhana, didapat nilai $\mathbf{0 , 6 7 3}$, yang berarti nilai koefisien regresi bernilai positif $(+)$ maka dengan demikian dapat dikatakan bahwa media audio berpengaruh positif terhadap keterampilan berbicara $(Y)$. selain itu nilai signifikansinya adalah $\mathbf{0 , 0 0 2}$ yang lebih kecil dibandingkan 0,05 yang berarti hipotesis "Terdapat pengaruh dari penggunaan media audio terhadap keterampilan berbicara siswa pada mata pelajaran bahasa Arab" dapat diterima.

Uji korelasi dimaksudkan untuk mencari hubungan antara keterampilan menyimak dan keterampilan berbicara, hubungan itu terjadi karena ada hubungan sebab akibat, keterampilan menyimak dan berbicara dapat dikatakan berkorelasi jika perubahan pada keterampilan menyimak diikuti dengan perubahan keterampilan berbicara secara teratur dengan arah yang sama.

Uji korelasi antara keterampilan menyimak dan berbicara dilakukan dengan pengujian terhadap nilai posttest siswa dalam pembelajaran Bahasa Arab setelah menggunakan media audio. Analisis korelasi ini dilakukan dibantu dengan program SPSS.

Berdasarkan Nilai Signifikansi dari output SPSS diketahui antara Menyimak (X) dengan Berbicara(Y) nilai signifikansi 0,006, nilai ini lebih kecil dibandingkan angka pembanding 0,05 , atau dapat dituliskan sebagai $0,006<0,05$, yang berarti terdapat korelasi yang signifikan antara keterampilan menyimak dan berbicara. Berdasarkan tanda bintar SPSS ari output SPSS diketahui nilai Pearson Correlation yang dihubungkan antara masing-masing variabel mempunyai tanda bintang, ini berarti terdapat korelasi yang signifiakan antara variabel yang dihubungkan.

\section{Correlations}

\begin{tabular}{|ll|r|r|}
\hline & & $\begin{array}{c}\text { Menyima } \\
\text { k_X }\end{array}$ & $\begin{array}{r}\text { Berbicara } \\
\text { _Y }\end{array}$ \\
\hline Menyima & Pearson & 1 & $.654^{* *}$ \\
k_X & Correlation & & .006 \\
& Sig. (2-tailed) & 16 & 16 \\
\hline N & Pearson & $.654^{* *}$ & 1 \\
\hline Berbicara & & \\
-Y & Correlation & .006 & 16 \\
& Sig. (2-tailed) & 16 & 16 \\
& N &
\end{tabular}

**. Correlation is significant at the 0.01 level (2tailed).

Hasil tersebut menunjukkan bahwa antara keterampilan menyimak dan keterampilan berbicara memiliki hubungan yang signifikan/korelasi yang signifikan. Sehingga dapat diketahui seperti pada kajian teori yang menyebutkan bahwa keterampilan menyimak pada anak juga akan mempengaruhi keterampilan berbicara nya.

Berdasarkan hasil analisis korelasi ini juga dapat diambil pelajaran bahwa audio yang erat kaitannya dengan pendengaran/simakan peserta didik akan mampu membantu menguasai keterampilan keterampilan laim, terutama keterampilan berbicara, karena apa yang peserta didik dengar dan pahami akan memudahkan peserta didik berbicara.

Dengan kemampuan peserta didik menyimak dan berbicara bahasa Arab dengan baik, peserta didik akan mudah memahami pelajaran bahasa Arab yang akan terus berlanjut hingga ke perguruan tinggi. Dengan keterampilan menyimak dan berbicara juga akan memacu keterampilan menulis dan membaca dapat dikuasai dengan baik oleh peserta didik.

Kesimpulan 
Berdasarkan penelitian yang telah dilakukan, maka dapat disimpulkan:

1. Penggunaan media audio dapat meningkatkan keterampilan menyimak pada siswa yang dibuktikan dengan hasil analisis postest yang menunjukkan peningkatan nilai siswa masuk kedalam kategori tinggi. Selain itu dari hasil uji normalitas yang menunjukkan signifikansi $\quad 0,200$ sehingga dapat diketahui data yang diuji berdistribusi normal. Uji linearitas juga menunjukkan signifikansi 0,071 yang menandakan ada nya hubungan yang linear. Selanjutnya pada uji korelasi angka signifikansi 0,002 yang berarti adanya korelasi yang signifikan yang juga ditandai dengan tanda bintang. Untuk uji terakhir dilakukan dengan uji regresi sederhana yang menunjukkan nilai 0,795 yang bernilai positif, ini menandakan pengaruh media audio terhadap keterampila menyimak berpengaruh positif. Untuk memperkuat pengujian, dilakukan kembali dengan analisis nilai signifikansi yang didapat 0,002 yang kurang dari 0,05 sehingga dapat diyakini bahwa media audio berpengaruh terhadap keterampilan menyimak peserta didik dalam pelajaran Bahasa Arab.

2. Penggunaan media audio dapat meningkatkan keterampilan berbicara pada siswa yang dibuktikan dengan hasil analisis posttest yang

3. menunjukkan peningkatan nilai dalam kategori sedang. Kemudian hasil yang

\section{REFERENSI}

Hardini \& Puspitasari. (2012). Strategi Pembelajaran Terpadu (Teori, Konsep \& Implementasi). Yogyakarta: Familia

Hermawan, Acep. (2009). Metodologi Pembelajaran Bahasa Arab. Bandung: PT Remaja Rosdakarya Offset

Kusmana. (2011). Guru Bahasa Indonesia Profesional. Jakarta: Ketsa ditunjukkan dalam pengujian hipotesis yang diawali dengan uji normalitas menunjukkan nilai 0,200 yang berarti data yang diuji berdistribusi normal, lalu pada uji linearitas nilai signifikansi 0,301 menunjukkan adanya hubungan yang linear secara signifikan. Pada uji korelasi didapat nilai signifikansi 0,002 dan ditambah adanya tanda bintang yang menunjukkan adanya korelasi signifikan antara media audio dan berbicara, untuk mengujian selanjutnya adalah uji regresi sederhana yang menunjukkan angka 0,673 yang berarti media audio membawa pengaruh positif terhadap keterampilan berbicara. Untuk tahap analisis akhir dilakukan pengujian nilai signifikansi 0,002 lebih kecil yang dibandingkan dengan 0,05 sehingga dapat disimpulkan bahwa terdapat pengaruh dari penggunaan media audio terhadap keterampilan berbicara.

4. Pengujian korelasi antara keterampilan menyimak dan berbicara menunjukkan bahwa antara keterampilan menyimak dan keterampilan berbicara memiliki hubungan yang signifikan/korelasi yang signifikan. Ini dibuktikan dengan nilai signifikansi 0,006, nilai ini lebih kecil dibandingkan angka pembanding $\mathbf{0 , 0 5}$ sehingga dapat dikatakan terdapat korelasi yang signifikan antara keterampilan menyimak dan berbicara.

Munadi, Yudhi. (2012). Media Pembelajaran. Jakarta: Gaung Persada Press

Sanjaya, Wine. (2006). Strategi Pembelajaran. Jakarta: Kencana Prenada Media Group

Sugiyono. (2010). Metode Penelitian Pendidikan Pendekatan Kuantitatif, kualitatif, dan $R \& D$. Bandung: Alfabeta 
Jurnal Tarbiyah: Jurnal Ilmiah Kependidikan

Vol. 7 No. 2. Juli - Desember 2018 (75-85)

Susilana, Rudi. (2009). Media Pembelajaran (Hakikat, Pengembangan, Pengambilan dan Penilaian). Bandung: CW Wacana prima

Permendikbud No. 65 Tahun 2013 tentang Standar Proses Pendidikan Dasar dan Menengah

W.J.S Poerwadarminta. (1982). Kamus Umum Bahasa Indonesia. Jakarta: PT. AlMa'arif 